\title{
Comparison of validity of the Food Frequency Questionnaire and the Diet History Questionnaire for assessment of energy and nutrients intakes in an Iranian population
}

\author{
Fatemeh Toorang, ${ }^{1,2}$ Bahareh Sasanfar, ${ }^{1}$ Ahmad Esmaillzadeh, ${ }^{2,3,4}$ Soraiya Ebrahimpour-Koujan ${ }^{2}$ and Kazem Zendehdel ${ }^{1,5,6}$
}

${ }^{1}$ Cancer Research Center; ${ }^{5}$ Cancer Biology Research Center; ${ }^{6}$ Breast Diseases Research Center, Cancer Institute of Iran; ${ }^{2}$ Department of Community Nutrition, School of Nutritional Sciences and Dietetics; ${ }^{3}$ Obesity and Eating Habits Research Center, Endocrinology and Metabolism Molecular-Cellular Sciences Institute, Tehran University of Medical Sciences, Tehran, Islamic Republic of Iran (Correspondence to: Kazem Zendehdel: kzendeh@tums. ac.ir). ${ }^{4}$ Department of Community Nutrition, School of Nutrition and Food Science, Isfahan University of Medical Sciences, Isfahan, Islamic Republic of Iran.

\begin{abstract}
Background: Dietary intakes are important for development and prevention of chronic disease. The Food Frequency Questionnaire (FFQ) has been suggested as an acceptable feasible method for assessing the association of dietary intake and disease. However, FFQs are sensitive to dietary habits and culture and should be valid in the study population.

Aims: We investigated the validity of the Diet History Questionnaire (DHQ) and the Food Frequency Questionnaire in healthy Iranians.

Methods: Participants were healthy relatives of cancer patients in the Cancer Institute of Iran. They participated in faceto-face interviews. We took telephone based 24-hour recalls every 2 months over a 1-year period. Assuming the mean intakes of 24-hour recalls as the gold standard, we estimated Pearson correlation coefficients to measure the reliability of the FFQ and the DHQ. We investigated how the FFQ or DHQ categorized individuals in different intake groups comparing with the 24-hour recalls.

Results: Overall, 102 subjects took part in our study. Deattenuated Spearman correlations were $\geq 0.5$ for energy, carbohydrate, protein, carotene, niacin, folate, vitamin $\mathrm{B}_{12}$, biotin, vitamin $\mathrm{C}$, iron, zinc and selenium in both $\mathrm{DHQ}$ and FFQ. Level of agreement with 24-hour recall in classifying individuals into different categories of intakes ranged from 0.81 for riboflavin and carotene to 0.92 for carbohydrate and zinc in the DHQ and from 0.75 for riboflavin to 0.96 for carbohydrate in the FFQ.
\end{abstract}

Conclusions: Both DHQ and FFQ were valid in assessing most nutrient intakes and classifying individuals in different categories of intakes in the Iranian population.

Keywords: food frequency questionnaire, diet history questionnaire, validation

Citation: Toorang F; Sasanfar B; Esmaillzadeh A; Ebrahimpour-Koujan S; Zendehdel K. Comparison of validity of the Food Frequency Questionnaire and the Diet History Questionnaire for assessment of energy and nutrients intakes in an Iranian population. East Mediterr Health J. 2020;26(9):10621069. https://doi.org/10.26719/emhj.19.099

Received: 25/04/18; accepted: 04/12/18

Copyright (C) World Health Organization (WHO) 2020. Open Access. Some rights reserved. This work is available under the CC BY-NC-SA 3.o IGO license (https://creativecommons.org/licenses/by-nc-sa/3.o/igo)

\section{Introduction}

Dietary intakes are increasingly recognized as key contributing factors in the development of several chronic diseases (1). However, assessment of long-term dietary intakes in epidemiologic studies is always challenging $(2,3)$.

The Food Frequency Questionnaire (FFQ) has been suggested as an acceptable (and the most feasible) method for collecting usual dietary intake data in epidemiologic studies (4). Several valid FFQs are available in the Islamic Republic of Iran, however, most have been designed for special groups or were used for assessing only a few nutrients or food groups. Two of these FFQs were used in the Golestan Cohort Study and the Tehran Lipid and Glucose Study $(5,6)$. Both were designed to examine usual dietary intakes that are related to the risk of cancer or cardiovascular disease. The validity of the FFQ in the Golestan Cohort Study has been examined only in
Golestan province, a small state in the northern part of the country (5); the one in the Tehran Lipid and Glucose Study has been validated for people living in Tehran (6), however, FFQs are sensitive to the dietary habits and dietary culture of the studied population (7). It seems that these FFQs are not appropriate for capturing dietary data from a socioeconomically diverse population with a wide range of variations in dietary intake. It must also be borne in mind that these FFQs do not have information on cooking methods, which might be an important contributing factor to disease incidence (4).

We developed a new FFQ for finding dietary determinants of cancer, based on the one suggested by American National Cancer Institute, in which we incorporated a food list along with questions about dietary habits and cooking methods. Its innovative ability to measure added fats and cooking methods makes it superior to available FFQs (8). However, its validity needs 
to be examined before application in large-scale studies in the country.

This study aimed to examine the validity of a newly developed Diet History Questionnaire (DHQ) against 24-hour recall to assess energy and nutrient intakes in healthy Iranian participants. We also compared the accuracy of the DHQ and the Golestan FFQ for estimating nutrient intakes in this study.

\section{Methods}

\section{Study participants}

We recruited 102 apparently healthy adults aged 20+ years who were selected from relatives of patients admitted to the Cancer Institute in Tehran between April 2011 and February 2012. According to Willet, the number of participants required to detect validation of a food frequency questionnaire is 110; a sample size larger than 150 subjects provides little additional precision and precision level in validation studies with less than 30 subjects is unacceptable (3). We initiated the study with larger sample size as we expected a sizable number would be lost to fallow-up. We recruited individuals from different age groups in 5-year strata. The participants were recruited after evaluation of the study criteria and signing written informed consent. Required information on demographic variables and medical history was obtained via a questionnaire. Exclusion criteria were pregnancy or lactation among women or being on a special diet for any reason.

\section{Developing food questionnaires}

The DHQ was developed by a group of nutritionists based on the Diet History Questionnaire of the American National Cancer Institute. Initially, a comprehensive list of food and mixed dishes was prepared based on earlier studies in the country $(5,6)$. Then, those with greater nutrient density and the highest frequency consumption were included in the questionnaire. We also considered foods that contributed to between-person variations. Ultimately, this DHQ comprised 146 main questions related to mixed dishes and food items. For each food item in the questionnaire, multiple choice frequency response categories along with specified portion sizes were included. Frequency response categories were not the same for all items, varying from never to every day, and the number of choices was increased for more frequent foods like bread. Portion sizes were chosen based on normal portion size of that food item in the community. We also included questions along with every food item about dietary habits, including some information on fat content and cooking methods.

The FFQ was a 116-item semi-quantitative questionnaire asking about average frequency and portion size. It is based on food items rather than mixed dishes. Both the FFQ and the DHQ probe information related to average consumption during the previous 12 months.

\section{Study protocol}

The study was approved by the ethical committee of Tehran University of Medical Sciences. The interviewer explained the study procedures and obtained written informed consent from all participants. Face-to-face interviews were conducted to complete the DHQ. These were carried out by interviewers who had a degree in public health from the Cancer Institute of Iran. Subsequently, the participants were asked to take part in an additional interview to complete the FFQ one week after the first interview. It took about 45 minutes to complete the DHQ and 35 for the FFQ.

After this, participants were called by trained nutritionists every 2 months for one year to report their 24-hour food recalls. Each recalls interview took around 40 minutes. In all, 105 participants completed all the recalls. The participants provided detailed descriptions of each food, including the method of preparation and recipe for mixed dishes. All DHQ, FFQ and 24-hour recalls were checked by a trained nutritionist and incomplete questionnaires were rechecked through a phone call.

We used home measures such as spoon, ladle, platter, plate or bowl to help people remember the amount they ate. For mixed dishes, we asked women about how much of each ingredient they used to make the dish and how much they ate from it. For men, we asked questions related to the cooking methods and ingredients of mixed dishes from the person who was responsible for preparing the food.

\section{Calculation of food and nutrient intakes}

All questionnaires and recalls were checked by a trained nutritionist. Recalls were converted to grams/day and proper codes from a food composition table were allocated to each food by trained nutritionists in accordance with uniform procedures. As the Iranian food composition table is only for raw foods and covers limited nutrients and foods, we used the translated version of McCance and Widdowson's food composition table (9). However, we used the Iranian food composition table for some traditional Iranian foods such as kashk (10). For analysing mixed dishes, the ingredients reported by the participants were considered. For the DHQ, mixed dishes were analysed based on a standard recipe, modified based on recalls.

Data from the FFQ and DHQ were converted into grams/day in separate programs devised by the authors in STATA statistical software. Consumption of seasonal foods like fruits were asked based on their use in season and daily intakes were estimated according to the season these foods were available. For example, we asked. "How many times are you eating a given fruit (for instance peach) when it is available". The availability of each type of fruit was then discussed among a group of nutritionists and we determined the number of months each fruit was available in a given time, then we considered the frequency for 3 months of the year rather than whole year. For the DHQ, participants were asked 2 
questions about each food item, one about the season the food item was easily accessed in the market and another about other occasions. In both the DHQ and FFQ, we used the median portion size in cases where there was no answer to the portion size question. Based on grams of foods, we computed total energy and nutrient intakes for each participant.

\section{Statistical analysis}

Mean, median and standard deviation of intakes estimated by DHQ, FFQ and 24-hour recalls were reported. The log transformed data was used to reduce skewedness. Data were re-checked and cleaned after initial entry and after each step of the analysis. We excluded data from energy intakes outliers (3 persons) where the energy intake was $>2$ standard deviations (SDs) from the mean. They constituted less than $5 \%$ of participants and correlations were not extremely affected by the exclusion. All statistical analyses were performed in STATA, version 11.2.

The validity of FFQ and DHQ was estimated by comparing data with the average of 5 days of 24-hour recalls using Pearson correlation coefficients (11). Nutrient intakes were adjusted for energy intake and age using the residual method. Since reference methods like food records or 24-hour recalls are subject to day-to-day variations in dietary intake, the correlation between data from FFQs and dietary recall might be underestimated (12). Therefore, deattenuated correlation coefficients were estimated to modify the within-person variations in recalls $(13,14)$. To estimate the attenuated correlations, we estimated within- and between-person variations by 1-way analysis of variance, then we used the formula suggested by Willet for the calculation of deattenuated correlation coefficients (13).

We also classified participants in terms of their dietary intakes into tertiles. Then, we investigated how FFQ or DHQ allocated individuals in different intake groups, considering the 24-hour recalls as the standard method. We reported the results as percentage disagreement, adjacent agreement, and complete agreement. Agreement was computed by summing adjacent agreement and complete agreement.

\section{Results}

The mean age of the 102 participants in our study was 43.2 (SD 12.2) years. There were 62 males and 40 females. Their characteristics are shown in Table 1.

Estimated intakes of energy and nutrients by the 3 methods are shown in Table 2. The average energy intake was higher using the FFQ (2943 kcal) than recall (2762 kcal) and DHQ (2027 kcal). Participants reported the highest intakes of carbohydrate and protein in their recalls. The highest fat intake was estimated based on data from the FFQ.

Crude Spearman correlation coefficients between DHQ and 24-hour recall ranged from 0.15 for riboflavin to 0.55 for carbohydrate (Table 3). Deattenuated Spearman correlation coefficients between DHQ and 24-hour recall

\begin{tabular}{|c|c|c|}
\hline Characteristic & No. & $\%$ \\
\hline \multicolumn{3}{|l|}{ Marital status } \\
\hline Single & 20 & 19.6 \\
\hline Married & 82 & 80.4 \\
\hline \multicolumn{3}{|l|}{ Sex } \\
\hline Male & 62 & 60.8 \\
\hline Female & 40 & 39.2 \\
\hline \multicolumn{3}{|l|}{ Education level } \\
\hline Illiterate & 2 & 2.0 \\
\hline Lower than high school & 34 & 35.1 \\
\hline High school & 35 & 36.1 \\
\hline \multirow[t]{2}{*}{ University } & 27 & 27.8 \\
\hline & Mean & SD \\
\hline Age (years) & 43.2 & 12.3 \\
\hline Body mass index $\left(\mathrm{kg} / \mathrm{m}^{2}\right)$ & 25.3 & 0.5 \\
\hline
\end{tabular}

ranged from 0.31 for fat to 0.87 for biotin. Crude Spearman correlation coefficients between FFQ and 24-hour recall ranged from 0.02 for riboflavin to 0.61 for carbohydrate. Deattenuated Spearman correlation coefficients between DHQ and 24-hour recall ranged from 0.03 for riboflavin to 0.74 for iron.

Deattenuated Spearman correlation coefficients $\geq 0.5$ were obtained for energy, carbohydrate, protein, fibre, vitamin $A$, carotene, niacin, folate, vitamin $B_{12}$, biotin, vitamin $C$, sodium, magnesium, iron, zinc and selenium between DHQ and the average for 24-hour dietary recalls.

Comparing FFQ and the average of 24-hour dietary recalls, we found that the deattenuated Spearman correlation coefficients were $>0.5$ for energy, carbohydrate, protein, carotene, niacin, vitamin $\mathrm{B}_{6}$, folate, vitamin $B_{12}$, biotin, vitamin $C$, calcium, iron, zinc and selenium.

The fraction of participants classified into the correct or adjacent category, expressed as agreement, ranged from 0.81 for riboflavin and carotene to 0.92 for carbohydrate and zinc, comparing DHQ data with the 24-hour recall data (Table 4). The corresponding figures for FFQ ranged from 0.75 for riboflavin to 0.96 for carbohydrate.

\section{Discussion}

We studied the validity of the DHQ and FFQ for assessment of dietary intakes among the Iranian population. We found that both DHQ and FFQ were valid instruments for assessing long-term dietary intakes of several nutrients. There were slight differences between the DHQ and FFQ in assessing most of the nutrients; however, DHQ had additional questions about food preparation methods, which could be an advantage for studies on specific disease like cancer. The FFQ was slightly better 
Table 2 Estimated daily intake of energy and nutrients for Iranian adults $(n=102)$ using 24-hour recall, the Diet History Questionnaire (DHQ) and the Food Frequency Questionnaire (FFQ)

\begin{tabular}{|c|c|c|c|c|c|c|c|c|c|}
\hline \multirow[t]{3}{*}{ Nutrient } & \multicolumn{9}{|c|}{ Method } \\
\hline & \multicolumn{3}{|c|}{ 24-hour recall } & \multicolumn{3}{|c|}{ DHQ } & \multicolumn{3}{|c|}{ FFQ } \\
\hline & Mean & SD & Median & Mean & SD & Median & Mean & SD & Median \\
\hline Energy (kcal) & 2761.9 & 771.8 & 2784.9 & 2026.4 & 587.7 & 1926.7 & 2942.5 & 1502.7 & 2610.1 \\
\hline Carbohydrate (g) & 448.6 & 218.6 & 402.5 & 320.3 & 127.5 & 289.4 & 367.2 & 162.1 & 331.4 \\
\hline Protein (g) & 151.2 & 65.5 & $145 \cdot 3$ & 75.2 & 31.0 & 71.0 & 111.2 & $67 \cdot 3$ & 90.4 \\
\hline Fat (g) & 105.9 & 48.4 & 97.2 & 60.9 & 24.0 & 57.9 & 129.5 & 145.9 & 86.7 \\
\hline Fibre (g) & 27.1 & 11.9 & 24.3 & 15.9 & 5.56 & 15.3 & 23.8 & 7.6 & 22.6 \\
\hline Sucrose (g) & 47.6 & 25.5 & 41.2 & 39.85 & 28.3 & 34.7 & 62.6 & 43.1 & 50.5 \\
\hline Cholesterol (mg) & 419.2 & 242.4 & 374.9 & 200.3 & 141.5 & 166.7 & 207.6 & 287.3 & 123.0 \\
\hline Vitamin A (RE) & 1121.6 & 553.7 & 1020.8 & 650.4 & 337.8 & 574.6 & 8995.2 & 5770.2 & 7991.6 \\
\hline Carotene ( $\mu \mathrm{g})$ & 4689.0 & 2608.0 & 4119.9 & 3071.7 & 2636.1 & 2449.2 & 4114.5 & 2067.0 & 3864.9 \\
\hline Thiamine (mg) & 0.2 & 0.3 & 0.10 & 0.7 & 0.1 & 0.74 & 0.2 & 0.3 & 0.1 \\
\hline Riboflavin (mg) & 0.1 & 0.3 & 0.04 & 1.4 & 0.8 & 1.22 & 0.2 & 0.2 & 0.2 \\
\hline Niacin & 27.4 & $15 \cdot 5$ & 23.76 & 18.4 & 9.9 & 16.71 & 23.8 & 12.7 & 20.9 \\
\hline Vitamin $\mathrm{B}_{6}$ & 0.3 & 0.30 & 0.20 & 1.3 & 0.5 & 1.24 & 0.3 & 0.3 & 0.2 \\
\hline Folate $(\mu \mathrm{g})$ & 520.4 & 213.6 & 487.9 & 263.4 & 119.7 & 236.3 & 422.4 & 225.6 & $375 \cdot 5$ \\
\hline Vitamin $B_{12}$ & 3.5 & 2.4 & 2.92 & 3.3 & 5.2 & 1.8 & 3.86 & 5.6 & 2.4 \\
\hline Biotin & 71.5 & $35 \cdot 9$ & 66.5 & 30.2 & 16.30 & 26.0 & 43.6 & 19.1 & 39.4 \\
\hline Vitamin C (mg) & 256.4 & 116.2 & 237.7 & 137.2 & 87.5 & 121.3 & 225.1 & 121.3 & 196.3 \\
\hline Sodium (mg) & 3251.7 & 1668.3 & 2949.0 & 2107.7 & 831.1 & 1960.3 & 4670.4 & 2303.1 & 4023.9 \\
\hline Potassium (mg) & 6992.3 & 2983.4 & 6644.8 & 2990.6 & 1176.2 & 2697.0 & 4813.8 & 1676.3 & 4623.2 \\
\hline Calcium (mg) & 2295.0 & 1280.2 & 2201.4 & 752.0 & 263.7 & $717 \cdot 3$ & 948.3 & 541.7 & 802.9 \\
\hline Magnesium (mg) & 521.3 & 237.2 & 477.8 & 245.2 & 107.1 & 221.6 & 369.0 & 155.0 & 328.4 \\
\hline Iron (mg) & 24.7 & 16.4 & 20.8 & 19.9 & 7.8 & 18.9 & 25.2 & 14.7 & 21.2 \\
\hline Zinc (mg) & 17.7 & 8.4 & 17.5 & 8.0 & 3.2 & 7.35 & 9.4 & $5 \cdot 5$ & 7.8 \\
\hline Selenium (mg) & 123.0 & 73.8 & 103.5 & 89.1 & 43.5 & 79.9 & 110.2 & 69.3 & 92.4 \\
\hline
\end{tabular}

$S D=$ standard deviation; $R E=$ retinol equivalent

in assessing dietary intakes of carbohydrate, vitamin $\mathrm{B}_{12}$, calcium and iron; however, DHQ was better in assessing other nutrient intakes. Both questionnaires were appropriate for classifying individuals based on their dietary intakes.

Previous studies on the validity of the FFQ in the Iranian population (Golestan Cohort Study and Tehran Lipid and Glucose Study) showed higher correlations between data obtained from FFQ and those from 24hour dietary recalls $(5,6)$. However, participants in the Tehran Lipid and Glucose Study were more familiar with nutritional assessment as they frequently answered questionnaires related to dietary intake (6). The FFQ used in Golestan was designed and developed based on the local foods of Golestan province (5) and were different from our population. Moreover, both studies had a greater number of 24-hour recalls than our study, which can result in realistic correlations (3). Individual dietary intakes usually vary on different days; therefore, by increasing the number of recalls, a better estimate of mean usual intake of a person could be achieved. The attenuated correlations we reached in the current study were closer to those reported in previous studies. This indicates that differences in within-person variations in dietary intakes between these studies contributed to different findings $(6,15)$.

We applied the 24-hour dietary recall as a reference method, which could be considered a weakness in this study. It is known that there are several sources of bias common between FFQ and dietary recalls. Some studies used biomarkers as the gold standard, however there is no valid biomarker for most nutrients as they are controlled by biological homeostasis and absorption abilities. Therefore, validation studies generally use food records as a reference method (16) due to the less common biases between this method and the FFQ. Unlike the FFQ, however, dietary records do not rely on memory and are the most accurate method in assessing food intakes (3). However, we still believe that 24-hour dietary recall is the method of choice in our society due to the lack of adequate nutritional information and lack of experience in recording food consumption $(3,6)$. Iranian validation studies usually use 24-hour recalls as a reference method, and even National Cancer Institute of America has used it $(5,6,17)$. We took recalls year round, which is the strength of our study (18). Although self-administration of the 
Table 3 Correlation coefficients of energy and nutrient intake between mean 24-hour recall and the Diet History Questionnaire (DHQ) and the Food Frequency Questionnaire (FFQ) among Iranian adults $(n=102)$

\begin{tabular}{|c|c|c|c|c|c|c|c|c|}
\hline \multirow[t]{3}{*}{ Nutrient } & \multicolumn{8}{|c|}{ Method } \\
\hline & \multicolumn{4}{|c|}{ DHQ } & \multicolumn{4}{|c|}{ FFQ } \\
\hline & Crude & Deattenuated & $\begin{array}{c}\text { Energy and } \\
\text { age adjusted }\end{array}$ & $\begin{array}{c}\text { Energy } \\
\text { and age } \\
\text { adjusted and } \\
\text { deatenuated }\end{array}$ & Crude & Deattenuated & $\begin{array}{l}\text { Energy and } \\
\text { age adjusted }\end{array}$ & $\begin{array}{l}\text { Energy } \\
\text { and age } \\
\text { adjusted and } \\
\text { deatenuated }\end{array}$ \\
\hline Energy & 0.51 & 0.81 & 0.51 & 0.81 & 0.34 & 0.54 & 0.36 & 0.58 \\
\hline Carbohydrate & 0.55 & 0.63 & 0.09 & 0.10 & 0.61 & 0.69 & 0.09 & 0.10 \\
\hline Protein & 0.39 & 0.59 & 0.09 & 0.14 & 0.34 & 0.51 & 0.18 & 0.27 \\
\hline Fat & 0.16 & 0.31 & 0.10 & 0.20 & 0.22 & 0.42 & 0.22 & 0.42 \\
\hline Fibre & 0.35 & 0.70 & 0.22 & 0.44 & 0.11 & 0.22 & 0.06 & 0.11 \\
\hline Sucrose & 0.31 & 0.43 & 0.20 & 0.28 & 0.23 & 0.33 & 0.07 & 0.09 \\
\hline Cholesterol & 0.26 & 0.37 & 0.02 & 0.03 & 0.30 & 0.42 & 0.20 & 0.28 \\
\hline Vitamin A & 0.29 & 0.77 & 0.25 & 0.67 & 0.12 & 0.31 & 0.08 & 0.20 \\
\hline Carotene & 0.23 & 0.62 & 0.26 & 0.69 & 0.19 & 0.50 & 0.11 & 0.30 \\
\hline Thiamine & 0.35 & 0.41 & 0.42 & 0.50 & 0.18 & 0.22 & 0.07 & 0.08 \\
\hline Riboflavin & 0.15 & 0.32 & 0.03 & 0.06 & 0.02 & 0.03 & 0.05 & 0.11 \\
\hline Niacin & 0.46 & 0.61 & 0.17 & 0.22 & 0.38 & 0.50 & 0.23 & 0.31 \\
\hline Vitamin $B_{6}$ & 0.28 & 0.49 & 0.23 & 0.41 & 0.30 & 0.52 & 0.11 & 0.19 \\
\hline Folate & 0.31 & 0.68 & 0.31 & 0.68 & 0.25 & 0.54 & 0.08 & 0.17 \\
\hline Vitamin $\mathrm{B}_{12}$ & 0.20 & 0.50 & 0.15 & 0.38 & 0.25 & 0.64 & 0.19 & 0.48 \\
\hline Biotin & 0.27 & 0.87 & 0.19 & 0.61 & 0.21 & 0.68 & 0.28 & 0.91 \\
\hline Vitamin C & 0.20 & 0.52 & 0.14 & 0.37 & 0.19 & 0.50 & 0.07 & 0.19 \\
\hline Sodium & 0.44 & 0.57 & 0.20 & 0.25 & 0.32 & 0.42 & 0.06 & 0.08 \\
\hline Potassium & 0.36 & 0.44 & 0.26 & 0.31 & 0.20 & 0.25 & 0.07 & 0.09 \\
\hline Calcium & 0.28 & 0.42 & 0.14 & 0.20 & 0.34 & 0.50 & 0.25 & 0.38 \\
\hline Magnesium & 0.41 & 0.55 & 0.20 & 0.27 & 0.25 & 0.34 & 0.09 & 0.12 \\
\hline Iron & 0.39 & 0.70 & 0.03 & 0.05 & 0.42 & 0.74 & 0.26 & 0.47 \\
\hline Zinc & 0.30 & 0.84 & 0.03 & 0.09 & 0.22 & 0.61 & 0.08 & 0.21 \\
\hline Selenium & 0.51 & 0.68 & 0.19 & 0.26 & 0.49 & 0.65 & 0.28 & 0.37 \\
\hline
\end{tabular}

DHQ is easy and low cost, we preferred the intervieweradministered approach due to low literacy level in our study population.

\section{Conclusion}

In conclusion, we found that the DHQ was a valid tool for measurement of long-term nutrient intakes in epidemio- logical studies in the Iranian population. Both questionnaires were too long and time-consuming and, thus, the approach to administering these questionnaires should be chosen cautiously. The DHQ provides detailed information about cooking methods and seasoning habits of individuals, which is more appropriate for epidemiological studies on cancer and other noncommunicable diseases.

\section{Acknowledgement}

We are indebted to the participants for their cooperation.

Funding: This study was supported by a grant for research from Tehran University of Medical Sciences (No. 11360).

Competing interests: None declared. 
Table 4 Agreement, adjacent agreement and complete disagreement of the Food Frequency Questionnaire (FFQ)-, the Diet History Questionnaire (DHQ)-driven intakes and average 24-hour recall among Iranian adults $(n=102)$

\begin{tabular}{|c|c|c|c|c|c|c|c|c|}
\hline \multirow[t]{3}{*}{ Nutrient } & \multicolumn{8}{|c|}{ Method } \\
\hline & \multicolumn{4}{|c|}{ DHQ } & \multicolumn{4}{|c|}{ FFQ } \\
\hline & Agreement & $\begin{array}{l}\text { Complete } \\
\text { agreement }\end{array}$ & $\begin{array}{c}\text { Adjacent } \\
\text { agreement }\end{array}$ & $\begin{array}{c}\text { Complete } \\
\text { disagreement }\end{array}$ & Agreement & $\begin{array}{l}\text { Complete } \\
\text { agreement }\end{array}$ & $\begin{array}{c}\text { Adjacent } \\
\text { agreement }\end{array}$ & $\begin{array}{c}\text { Complete } \\
\text { disagreement }\end{array}$ \\
\hline Energy & 0.90 & 0.50 & 0.40 & 0.09 & 0.86 & 0.44 & 0.43 & 0.14 \\
\hline Carbohydrate & 0.92 & 0.48 & 0.44 & 0.07 & 0.96 & 0.61 & 0.35 & 0.04 \\
\hline Protein & 0.88 & 0.43 & 0.45 & 0.11 & 0.87 & 0.51 & 0.36 & 0.13 \\
\hline Fat & 0.83 & 0.38 & 0.45 & 0.17 & 0.77 & 0.46 & 0.32 & 0.18 \\
\hline Fibre & 0.85 & 0.43 & 0.42 & 0.14 & 0.87 & 0.43 & 0.45 & 0.13 \\
\hline Sucrose & 0.90 & 0.50 & 0.40 & 0.09 & 0.86 & 0.44 & 0.43 & 0.14 \\
\hline Cholesterol & 0.86 & 0.40 & 0.46 & 0.13 & 0.85 & 0.44 & 0.42 & 0.15 \\
\hline Vitamin A & 0.82 & 0.39 & 0.43 & 0.18 & 0.80 & 0.36 & 0.45 & 0.20 \\
\hline Carotene & 0.81 & 0.36 & 0.45 & 0.18 & 0.82 & 0.42 & 0.41 & 0.18 \\
\hline Thiamine & 0.83 & 0.36 & 0.47 & 0.16 & 0.83 & 0.34 & 0.49 & 0.17 \\
\hline Riboflavin & 0.81 & 0.37 & 0.44 & 0.18 & 0.75 & 0.24 & 0.51 & 0.25 \\
\hline Niacin & 0.87 & 0.45 & 0.42 & 0.12 & 0.88 & 0.48 & 0.41 & 0.12 \\
\hline Vitamin $B_{6}$ & 0.86 & 0.45 & 0.42 & 0.13 & 0.84 & 0.40 & 0.45 & 0.16 \\
\hline Folate & 0.80 & 0.37 & 0.43 & 0.19 & 0.88 & 0.38 & 0.50 & 0.12 \\
\hline Vitamin $B_{12}$ & 0.85 & 0.43 & 0.41 & 0.15 & 0.84 & 0.49 & 0.36 & 0.16 \\
\hline Biotin & 0.82 & 0.39 & 0.43 & 0.17 & 0.81 & 0.41 & 0.41 & 0.19 \\
\hline Vitamin C & 0.90 & 0.45 & 0.45 & 0.09 & 0.85 & 0.44 & 0.42 & 0.15 \\
\hline Sodium & 0.87 & 0.44 & 0.43 & 0.12 & 0.86 & 0.42 & 0.45 & 0.14 \\
\hline Potassium & 0.85 & 0.46 & 0.39 & 0.14 & 0.87 & 0.47 & 0.41 & 0.13 \\
\hline Calcium & 0.88 & 0.45 & 0.43 & 0.11 & 0.84 & 0.42 & 0.43 & 0.16 \\
\hline Magnesium & 0.87 & 0.49 & 0.38 & 0.12 & 0.90 & 0.47 & 0.44 & 0.10 \\
\hline Iron & 0.87 & 0.43 & 0.44 & 0.13 & 0.84 & 0.44 & 0.41 & 0.16 \\
\hline Zinc & 0.92 & 0.51 & 0.41 & 0.08 & 0.89 & 0.45 & 0.45 & 0.11 \\
\hline Selenium & 0.87 & 0.42 & 0.45 & 0.13 & 0.85 & 0.37 & 0.49 & 0.15 \\
\hline
\end{tabular}

\section{Comparaison de la validité du questionnaire de fréquence alimentaire et du questionnaire sur les habitudes alimentaires dans l'évaluation des apports en énergie et en nutriments dans une population iranienne \\ Résumé}

Contexte : Les apports alimentaires sont essentiels au développement, ainsi qu'à la prévention des maladies chroniques. Le questionnaire de fréquence alimentaire a été proposé comme une méthode acceptable et pratique pour évaluer le lien entre les apports alimentaires et les maladies. Cependant, les questionnaires de fréquence alimentaire sont soumis à l'influence des habitudes alimentaires et de la culture ; ils devraient donc être validés pour la population d'étude.

Objectifs : Nous avons examiné la validité du questionnaire sur les habitudes alimentaires et du questionnaire de fréquence alimentaire chez des Iraniens en bonne santé.

Méthodes : Les participants à cette étude étaient des proches en bonne santé de personnes touchées par le cancer, soignées au centre anticancéreux de la République islamique d'Iran. Ils ont participé à des entretiens en présentiel. Nous avons ensuite effectué des rappels de 24 heures par téléphone tous les deux mois sur une période d'un an. En prenant pour référence les apports moyens obtenus au moyen des rappels de 24 heures, nous avons estimé les coefficients de corrélation de Pearson afin de mesurer la fiabilité du questionnaire de fréquence alimentaire et du questionnaire sur les habitudes alimentaires. Nous avons examiné la manière dont les deux questionnaires répartissaient les participants en différentes catégories d'apports alimentaires, par comparaison avec les rappels de 24 heures.

Résultats : Au total, 102 sujets ont participé à notre étude. Les corrélations de Spearman corrigées pour l'atténuation étaient supérieures ou égales à 0,5 pour l'énergie, les glucides, les protéines, le carotène, la niacine, le folate, la vitamine $B_{12}$, la biotine, la vitamine $C$, le fer, le zinc et le sélénium dans les deux questionnaires. Le niveau de concordance avec le rappel des 24 heures pour la classification des sujets dans les différentes catégories d'apports alimentaires allait de 
0,81 pour la riboflavine et le carotène à 0,92 pour les glucides et le zinc dans le questionnaire sur les habitudes alimentaires, et de 0,75 pour la riboflavine à 0,96 pour les glucides dans le questionnaire de fréquence alimentaire.

Conclusions : Le questionnaire de fréquence alimentaire et le questionnaire sur les habitudes alimentaires convenaient tous deux pour évaluer la plupart des apports nutritionnels ainsi que pour classifier les participants en différentes catégories d'apports alimentaires dans la population iranienne.

$$
\begin{aligned}
& \text { التحقق من صحة استبيان تواتر الغذاء مقابل استبيان تاريخ النظام الغذائي لتقييم الطاقة ومدخو لات العناصر } \\
& \text { الغذائية لدى مجموعة من السكان الإير انيين } \\
& \text { فاطمة تورنج، بهاريح ساسنفر، أحمد إسماعيل زاده، ثريا إبراهيم بور كوجانئ الإنئ كاظم زنديهدل }
\end{aligned}
$$

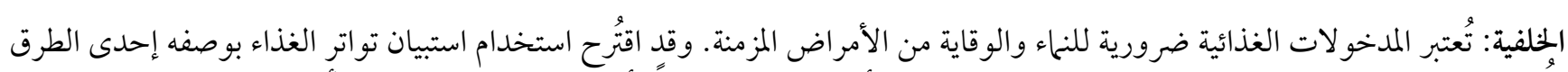

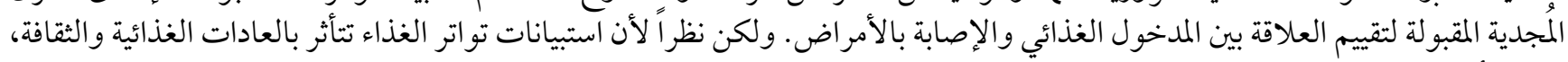

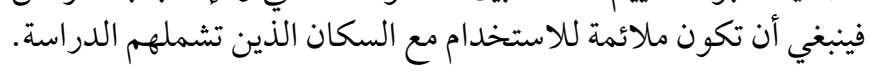

الأهداف: هدفت هذه الدراسة إلى تحري صحة استبيان تاريخ النظام الغذائي، واستبيان تواتر الغذاء لتطبيقها على مستوى الإيرانيين الأصحاء.

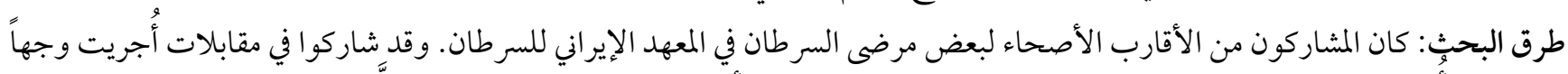

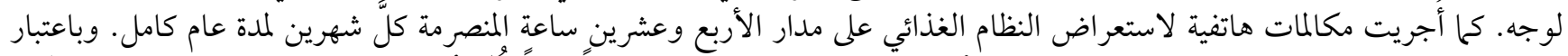

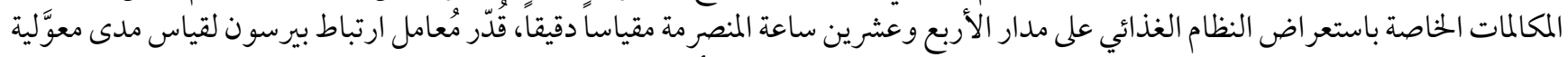

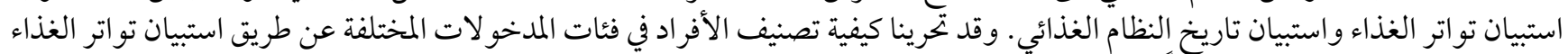

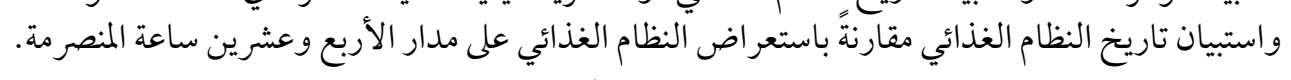

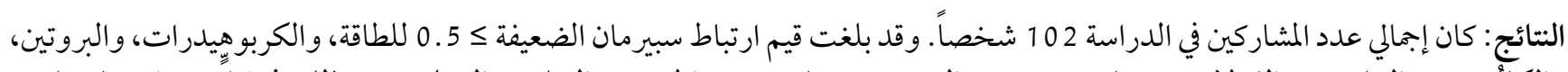

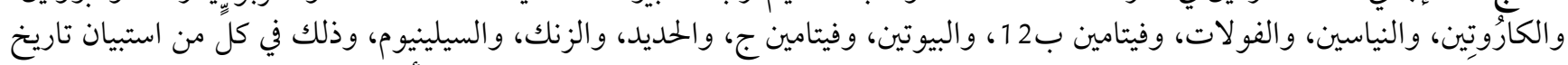

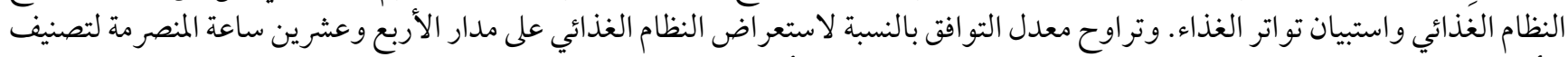

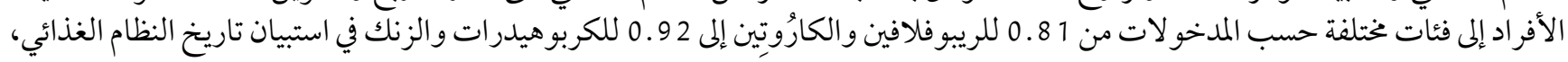

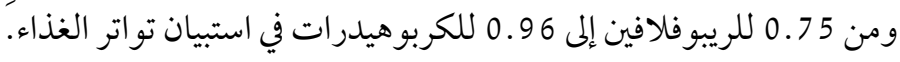

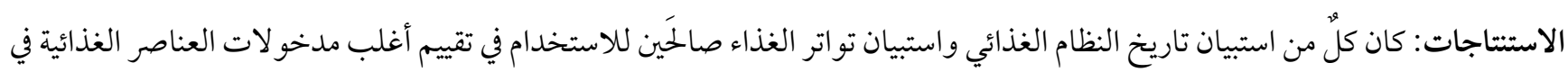
الفئات المختلفة للمدخو لات كن بين السكان الإيرانيين.

\section{References}

1. Amuna P, Zotor FB. Epidemiological and nutrition transition in developing countries: impact on human health and development: the epidemiological and nutrition transition in developing countries: evolving trends and their impact in public health and human development. Proceedings of the Nutrition Society. 2008;67(1):82-90. https://doi.org/10.1017/So029665108006058

2. Kaaks R. Biochemical markers as additional measurements in studies of the accuracy of dietary questionnaire measurements: conceptual issues. Am J Clin Nutr. 1997;65(4):1232S-9S. doi:10.1093/ajcn/65.4.1232S

3. Willett W. Nutritional epidemiology, 3rd ed. Oxford: Oxford University Press; 2012.

4. Subar AF, Thompson FE, Kipnis V, Midthune D, Hurwitz P, McNutt S, et al. Comparative validation of the Block, Willett, and National Cancer Institute food frequency questionnaires: the Eating at America's Table Study. Am J Epidemiol. 2001;154(12):1089-99. doi:10.1093/aje/154.12.1089

5. Malekshah A, Kimiagar M, Saadatian-Elahi M, Pourshams A, Nouraie M, Goglani G, et al. Validity and reliability of a new food frequency questionnaire compared to $24 \mathrm{~h}$ recalls and biochemical measurements: pilot phase of Golestan cohort study of esophageal cancer. Eur J Clin Nutr. 2006;60(8):971. doi:10.1038/sj.ejcn.1602407

6. Mirmiran P, Esfahani FH, Mehrabi Y, Hedayati M, Azizi F. Reliability and relative validity of an FFQ for nutrients in the Tehran Lipid and Glucose Study. Public Health Nutr. 2010 May;13(5):654-62. doi:10.1017/S1368980009991698

7. Ngo J, Gurinovic M, Frost-Andersen L, Serra-Majem L. How dietary intake methodology is adapted for use in European immigrant population groups-a review. Br J Nutr. 2009 Jul;101 Suppl 2:S86-94. doi:10.1017/Sooo7114509990614

8. Block G, Woods M, Potosky A, Clifford C. Validation of a self-administered diet history questionnaire using multiple diet records. J Clin Epidemiol. 1990;43(12):1327-35. doi:10.1016/0895-4356(90)90099-b

9. Dorosti A, Tabatabaei M. Food composition table. Iran Nutr World J. 2007;16:15-20. 
10. Azar M, Sarkisian E. Food composition table of Iran. Tehran: National Nutrition and Food Research Institute, Shaheed Beheshti University; 1980;65.

11. Cade J, Thompson R, Burley V, Warm D. Development, validation and utilisation of food-frequency questionnaires-a review. Public Health Nutr. 2002 Aug;5(4):567-87. PMID:12186666

12. Boushey CJ, Coulston AM, Rock CL, Monsen E, eds. Nutrition in the prevention and treatment of disease. Boston: Elsevier; 2001.

13. Willet W. Correction for the effects of measurement error. In: Willet W, ed. Nutritional epidemiology, 2nd ed. Oxford: OUP; 1998. doi:10.1093/acprof:0so/9780199754038.003.0012

14. Rosner B, Willett W. Interval estimates for correlation coefficients corrected for within-person variation: implications for study design and hypothesis testing. Am J Epidemiol. 1988;127(2):377-86. doi:10.1093/oxfordjournals.aje.a114811

15. Ocke MC, Bueno-de-Mesquita HB, Pols MA, Smit HA, van Staveren WA, Kromhout D. The Dutch EPIC food frequency questionnaire. II. Relative validity and reproducibility for nutrients. Int J Epidemiol . 1997;26(Suppl. 1):S49. doi:10.1093/ije/26.suppl_1.s49

16. Ahn Y, Kwon E, Shim JE, Park MK, Joo Y, Kimm K, et al. Validation and reproducibility of food frequency questionnaire for Korean genome epidemiologic study. Eur J Clin Nutr. 2007;61:1435. doi:10.1038/sj.ejcn.1602657

17. Subar AF, Thompson FE, Kipnis V, Midthune D, Hurwitz P, McNutt S, et al. Comparative Validation of the Block, Willett, and National Cancer Institute food frequency questionnaires The Eating at America's Table Study. Am J Epidemiol. 2001;154(12):1089-99. doi:10.1093/aje/154.12.1089

18. Serra-Majem L, Andersen LF, Henríque-Sánchez P, Doreste-Alonso J, Sánchez-Villegas A, Ortiz-Andrelluchi A, et al. Evaluating the quality of dietary intake validation studies. Br J Nutr. 2009 Dec;102 Suppl 1:S3-9. doi:10.1017/Sooo7114509993114. 